\title{
4
}

\section{Lending Crowdfunding: Principles and Market Development}

\author{
Tania Ziegler and Rotem Shneor
}

\section{Introduction}

The crowdfunding phenomenon has entered the world stage with the advent of lending-based crowdfunding in the mid-2000s as two new platforms emerged from both sides of the Atlantic. Zopa was established in the UK in 2005, and briefly afterwards Prosper was established in the United States in 2006. Both broke grounds by mediating between private

\section{T. Ziegler $(\bowtie)$}

Cambridge Centre for Alternative Finance, Judge Business School, University of Cambridge, Cambridge, UK

e-mail: t.ziegler@jbs.cam.ac.uk

R. Shneor $(\bowtie)$

School of Business and Law, University of Agder, Kristiansand, Norway e-mail: rotem.shneor@uia.no 
lenders and borrowers via dedicated websites, which bypassed traditional financial institutions while benefiting from fees on successful transactions (Bachmann et al. 2011).

The new phenomenon was labelled as Peer-to-Peer (hereafter 'P2P') Lending. Since its emergence, P2P lending has offered good returns to investors and lower cost of capital to borrowers (Hollas 2013). Such model allowed borrowers to receive a loan without a financial institution involvement and a possibility of receiving better conditions than those offered by traditional credit providers (Bachmann et al. 2011). For lenders, the new model presented a new investment and portfolio diversification opportunities, where risk was coupled with credit ratings of loans, and which offered better returns than some of the existing products (ibid.).

The phenomenon received a further push following the global financial crisis as a consequence of the drying up of traditional financing (Bruton et al. 2015). Such development was part of a wider Financial Technology (FinTech) industry development in which technological changes enabled new practices and business models disrupting traditional financial services while building on a degree of user distrust towards traditional institutions following the financial crisis (Haddad and Hornuf 2019). Furthermore, alternative finance models carried the potential to unlock access to finance for individual and business borrowers who might have previously been excluded or marginalised by traditional lending practices (Serrano-Cinca et al. 2015). For both borrowers and investors, the crowdlending space offers unprecedented access, as the barrier to entry is often low, with some platforms offering a minimum investment as little as $\$ 1$, while the minimum and maximum loan amounts on platforms range from a few dollars, to several million dollars. Hence, overall, crowdlending can offer more diverse sources of funding for the real economy in countries that have previously over-relied on bank lending for growth.

During the last decade, the industry has seen a proliferation of debtbased crowdfunding models from P2P lending to Balance Sheet lending, Invoice Trading, and Debt-based Securities, jointly referred to from now onwards as 'Crowdlending'. Such models have dominated the crowdfunding industry throughout its brief history, with crowdlending almost 
doubling in size every year. In 2018, crowdlending models accounted for $97 \%$ of the USD 300 billion global crowdfunding industry, while exhibiting an average year-on-year growth rate of $93 \%$ since 2014 (Ziegler et al. 2020).

Unsurprisingly, in light of this impressive growth, and thanks to its related efficiency gains, some began suggesting that crowdlending represents a real challenge to traditional finance (Hollas 2013; Kotarba 2016). However, others suggest that FinTech solutions may both complement existing financing channels as well as fill market needs from which traditional institutions have withdrawn (Haddad and Hornuf 2019). Indeed, recent empirical evidence clearly shows that traditional financial institutions actively participate in crowdlending and represent an important portion of related volumes (Ziegler et al. 2020).

In this chapter we review the current state of crowdlending. First, we present important milestones in its brief history followed by a detailed classification of the crowdlending model types that have emerged in this period. Next, we present facts and figures reflecting the current state of crowdlending both at global and regional levels. This is followed by a brief review of the mechanisms underlying crowdlending platform operations, supported by insights from current knowledge and existing research. Our chapter then concludes with suggestions for future research, as well as some implications for practice.

\section{A Brief History of Crowd Lending}

Crowdlending originated from the emergence of P2P Lending with the launching of ZOPA (Bachmann et al. 2011). Being the first P2P lending platform, ZOPA began its operation in 2005, while originating personal loans to British consumers through funds provided by retail investors. In this respect, individual investors would be matched to borrowers as related to their own lending criteria and appetite, bypassing conventional lending processes. Nearly 15 years on, Zopa was set to become the first 'Unicorn' of the Digital Lending era (Armstrong 2018).

Within a year, the US-based platform Prosper was launched and closely followed up by Lending Club, both focusing on the consumer lending 
market as well as on refinancing of student loans. P2P lending activities in the United States have some critical contextual differences that should be highlighted. The first relates to how the industry self-identifies. In the United States, firms have broadly adopted the moniker of 'marketplace' instead of 'peer-to-peer' largely to reflect the difference of stakeholders that utilise their services. The United States tends to rely heavily on sale of full or partial loans to institutional or professional investors, rather than focusing on matching retail individuals to borrowers (Milne and Parboteeah 2016). In this respect, the firms act more in a syndicate manner, creating a mechanism for matching loan-notes to interested investors.

As this marketplace began to grow quickly within the United States, concerns over how to best regulate it also emerged. By 2008, the Securities and Exchange Commission of the United States began to require P2P Lending firms (marketplace lenders) to register the loans executed on their platform as a security (Barry 2019). Specifically, investors would be purchasing non-recourse notes representing fractional interests in specific underlying consumer loans (Popescu 2016). Though this was the first example of regulating the P2P Lending industry, regulation of alternative finance activities in the United States is arguably still in flux. Notably, the JOBS Act was not signed into law until 2012, with a slow roll-out of legislation and regulatory guidance that persists in the United States as of today.

By 2010, examples of P2P Lending FinTech firms began to emerge worldwide, with some of the first examples of P2P lending focused on the Small and Medium-sized Enterprises (hereafter 'SME') or Business borrower space. Since their launch in 2010, Funding Circle became one of the first FinTech firms to apply the P2P lending model specifically to business loans (Milne and Parboteeah 2016). Though the consumer lending model remains the single largest iteration of P2P Lending, the asset class has expanded significantly, with firms now offering business loans, property loans, mortgages, and an array of other debt-facilities.

In 2011, the first P2P Lending-focused trade-body emerged in the form of the UK's "Peer-to-Peer Finance Association". Though this tradebody has since ceased its activities, its emergence came at a critical point for the advancement of the landscape in the UK (Nixon 2020). This association implemented a code of conduct, effectively creating rules for 
'self-regulation' in advance of formal regulation of the industry. By 2013, the UK's Financial Conduct Authority launched its first consultation on Crowdfunding, which included digital lending activities referred to as 'loan-based crowdfunding'. Since 2014, the P2P lending market in the UK has fallen under the remit of the FCA. By 2016, examples of proposed or existing regulation of $\mathrm{P} 2 \mathrm{P} / \mathrm{Marketplace}$ activities was apparent globally.

By the end of the decade, crowdlending has become a global and mainstream activity, with platforms operating in nearly every country in the world. However, nowhere as prominently as in China, which grew to be the world's largest crowdlending market, estimated at USD 356 billion in 2017 (Ziegler et al. 2018). More specifically, China presents an interesting evolution path in a unique context characterized by relatively undeveloped regulatory environment, where loans are riskier than in the United States or the United Kingdom, the credit referencing system is not fully developed, and where loans are financed primarily by households (Milne and Parboteeah 2016).

However, recent years have seen growing concerns with fraud in the Chinese crowdlending space, especially following the collapse of platforms such as Ezubao, which was found to be operating as a "Ponzy scheme" (Zhang and Miller 2017). Late in 2016, the China Banking Regulatory Commission issued interim rules for regulating the P2P lending industry, in an effort to limit credit risk (Chorzempa 2018). This was necessary to address problems where Chinese platforms were acting more like deposit takers with creation of a 'capital pool', with retail investors effectively lending to the platform rather than funding specific loans or loan-parts intermediated by the platforms, as elsewhere. This crackdown has led to a course correction, with the Chinese crowdlending market seeing a 34\% decline in market volume between 2017 and 2018 (Ziegler et al. 2020). Following regulatory crackdown and the exit of platforms suspected of questionable practices, it is expected that the market may gradually recover in the future, but it remains unclear how quickly and to what extent such recovery will occur. Despite this decline, China remains the largest crowdlending market in the world with a volume of close to USD 215 billion in 2018 (ibid.). 


\section{A Continually Evolving Classification of Models}

While the concept of private individuals lending money without mediation is not new or revolutionary, what makes crowdlending a new phenomenon is the conduct of such transactions over the Internet while using online platforms (Bachmann et al. 2011). Most importantly, these are nondeposit taking platforms that facilitate online credit (through either secured or unsecured loans) to individuals or business borrowers, with capital lent by individuals or institutional investors. These platforms, and the models they represent, have evolved as a response to the gaps in the traditional credit market dominated by banks, and live outside of the incumbent or traditional debt ecosystem.

Crowdlending, also referred to as 'FinTech Credit', can be defined as all credit activity facilitated by platforms that match borrowers with lenders (investors) and includes activities referred to as "P2P lending", "loanbased crowdfunding" or "marketplace lending" and also may include platforms that use their own balance sheet to intermediate between borrowers and lenders (Bank for International Settlements and Financial Stability Board 2017).

This chapter will adopt the classification used and developed by the Cambridge Centre for Alternative Finance (CCAF) in its annual industry bench-marking reports (e.g. Ziegler et al. 2020). This classification includes a variety of alternative finance lending models that fall under the broader scope of FinTech Credit. In the text that follows, definitions and terms provided are adopted from the CCAF reports, unless stated otherwise.

First, Peer-to-peer (P2P) Lending - is a model in which a group of individual or institutional investors provide a loan (secured or unsecured) to a consumer or business borrower. In its most orthodox form, the P2P lending platform acts as a marketplace that connects the borrower and investor(s) such that the risk of financial loss if the loan is not repaid is with the investor and not with the platform. Depending upon the jurisdiction, this model may be referred to as Loan-based Crowdfunding, Marketplace Lending, or Collaborative Financing.

The mechanics, as graphically presented in Fig. 4.1, are as follows. The P2P lending firm provides potential borrowers with an easily accessible 


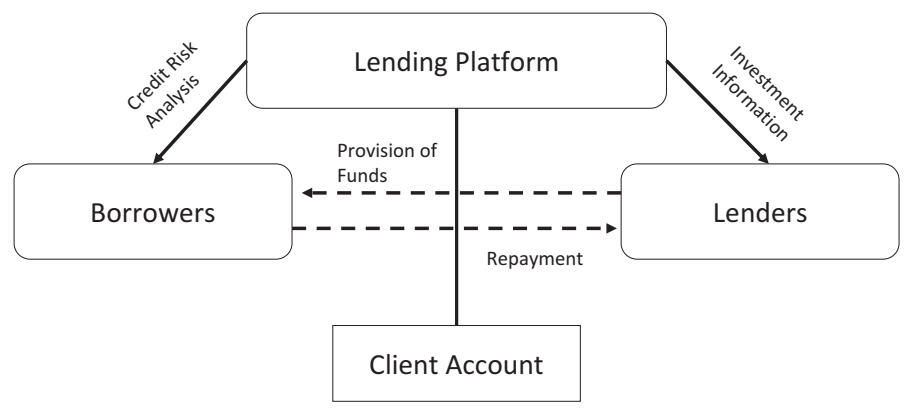

Fig. 4.1 Traditional P2P lending model. (Source: Bank for International Settlements and Financial Stability Board (2017). Market structure, business models and financial stability implications Bank for International Settlements. The full publication is available on the BIS website free of charge: www.bis.org)

and low-cost loan application, which is processed on an online platform. In most cases, the P2P lending firm will rely upon traditional credit scoring facilities and borrower-provided financial information in order to assess the borrower's affordability, loan price, and rating, while verifying the information provided within the loan application. Nevertheless, inhouse methodologies used for platforms' own loan risk assessment are difficult to ascertain, as these are proprietary and disclosure is limited (Bank for International Settlements and Financial Stability Board 2017). With the advent of Open Banking, APIs to connect to individualized financial data is on the rise, but this is largely occurring within the constraints of the European Union.

In the early days of P2P lending, investors would review individual loan applications and make the decision to lend their funds against their own assessment. In this respect, the P2P Lending firm would function only as an intermediary, executing the loan once self-matched by lenders. As the model has developed, it is now far more common for the lending platform to automatically match individual lenders against pre-selected loan criteria. Regardless, the platform is typically responsible for communicating appropriate credit grades, setting a pre-fixed interest rate (a shift away from auction models that were more popular at the inception of P2P lending) and servicing the loan once it has been originated. 


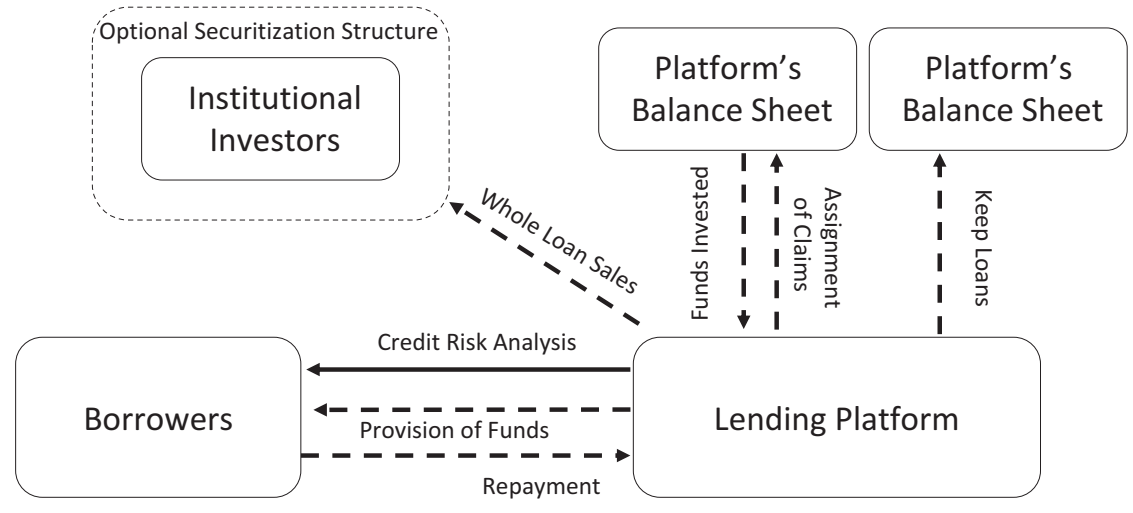

Fig. 4.2 Balance sheet lending model. (Source: Bank for International Settlements and Financial Stability Board (2017). Market structure, business models and financial stability implications Bank for International Settlements. The full publication is available on the BIS website free of charge: www.bis.org)

Second, Balance Sheet Lending-refers to a model in which a digital lending platform directly retains consumer or business loans (either whole loans or partial loans), using funds from the platform operator's balance sheet. These platforms therefore function as more than just intermediaries, originating and actively funding loans, so the risk of financial loss if the loan is not repaid is with the platform operator. In this respect, the platform operator looks more like a non-bank credit intermediary (Bank for International Settlements and Financial Stability Board 2017). The mechanics of this model are described in Fig. 4.2.

While the above represent the largest share of crowdlending volumes, as well as the most common practice. Recent years have seen the emergence of additional models such Invoice Trading, Debt-based Securities and Mini Bonds. Here, Invoice Trading, one of the fastest growing models, refers to an online marketplace where businesses can sell partial or whole receivables (invoices) at a discount. Individual lenders or institutional investors may serve as the counterparty in the sale transaction, again opening a new investment opportunity to a wider public of investors. This model is of particular importance for SMEs for raising shortterm debt by pre-financing their outstanding invoices through individual or institutional investors (Dorfleitner et al. 2017). 
Debt-based Securities are models where individuals or institutional funders purchase securities, typically a bond or debenture, at a fixed interest rate. And Mini Bonds refer to a model in which individuals or institutions purchase securities from companies in the form of an unsecured bond which is 'mini' because the issue size is much smaller than the minimum issue amount needed for a bond issued in institutional capital markets. Furthermore, Mini Bonds are not always transferable, either because the issue size is too small to provide secondary market liquidity or because prospectus exemptions require investors to hold the bond until maturity. Other terms can be very similar to traditional corporate bonds, such as being subject to early call provisions allowing the issuer to repay prior to maturity if its prospects improve.

\section{Extended Services and Functionalities}

As FinTech credit markets mature and the number of players increases, extended services and functionalities emerge. One type of such extensions may be identified in the emergence of aggregator platforms, which are tools that compile data from a range of platforms to allow borrowers to find suitable loan products from several crowdlending platforms in a centralised location. Aggregators offer an opportunity for lenders to compare loan products efficiently across platforms and better understand their different financing options. Aggregators may also act as brokers and potentially receive commission on referred business.

A second type of extension is associated with the establishment of secondary markets. In response to the largely illiquid nature of loan parts or traches held by investors, some platforms (or third-parties) have established secondary markets. In crowdlending, a secondary market acts as a marketplace that allows lenders to sell their loan parts before the loan reaches maturity. Here, the purchaser may be another lender or even the platform itself (in balance sheet lending). Loans may be sold at-a discount or premium, or they might be sold at par, assuming the loan is amortizing or repaid in accordance with the loan schedule. Where secondary markets are highly automated and the platform has discretion to buy and sell on behalf of investors, it is common for a standard valuation 
algorithm to assign values to each loan in real time, so that the platform can ensure it is swapping one loan for another of equivalent value. However, secondary markets for P2P loans are a relatively new development, not all platforms offer secondary markets, and many secondary markets are highly illiquid.

\section{The State of the Crowdlending Market}

In the current section we present the most up-to-date market data from the 2019 CCAF Global Alternative Finance Report (Ziegler et al. 2020). In 2018, the global alternative finance volumes amounted to just over $\$ 300$ billion, $97 \%$ of which derived from models that would fall under lending activities.

Since starting to track the alternative finance industry, the P2P Consumer Lending model has remained the single largest volume driver, accounting for $66 \%$ of all alternative lending volumes. This was followed by P2P Business Lending (17\%) and Balance Sheet Business Lending (7\%). Individual borrowers, or consumers, are the largest group of borrowers as illustrated in Fig. 4.3, driving Fintech Credit activities globally. Consumers are individuals, typically receiving an unsecured loan. Although loan size varies significantly by jurisdiction, individuals tend to borrow between USD $\$ 2,500-30,000$, with annual percentage rates ranging typically between $7 \%$ and $20 \%$. Borrowers use these loans to consolidate their debt or refinance credit on their credit cards; to purchase a vehicle, repay a student loan, pay utility bills or wedding expenses, or to cover the costs associated with illness or unexpected hardship. More specifically, it should be noted that research conducted by the CCAF suggests that borrowers using P2P or Balance Sheet Consumer Lending are increasingly seeking loans to support their business (sole-traders, microbusiness, early stage capital).

Table 4.1 presents the annual development in crowdlending volumes. While the industry has experienced a dramatic growth year-on-year since 2013 (when data was first collected), a notable drop can be observed in five of the eight applicable models between 2017 and 2018. This drop can be explained by market dynamics in China, while the rest of the world has seen continued healthy growth. 

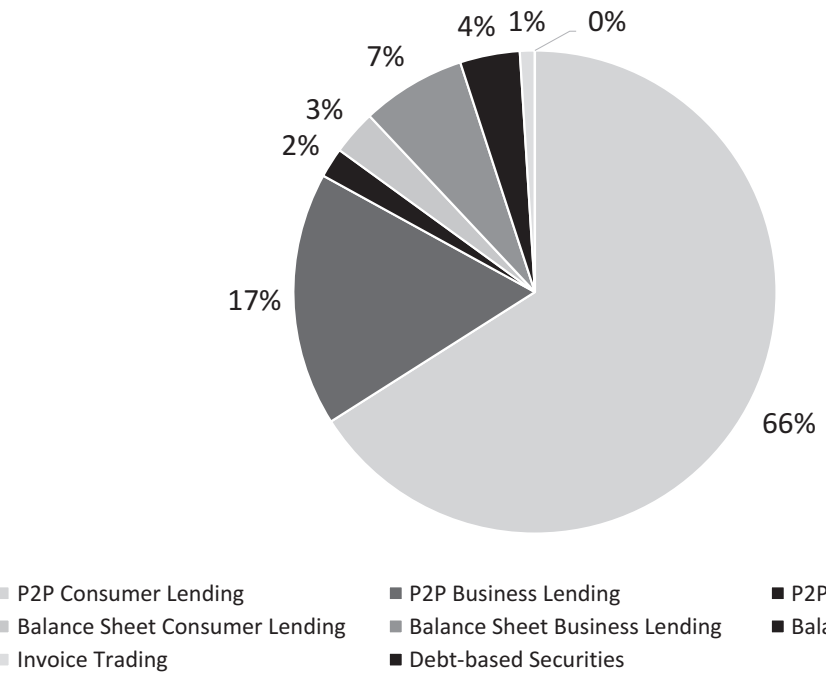

- P2P Business Lending

Balance Sheet Business Lending

- Debt-based Securities
- P2P Property Lending

- Balance Sheet Property Lending

Fig. 4.3 Proportion of global volume from key crowdlending models

Table 4.1 Global alternative lending in USD billion (inclusive of China figures)

\begin{tabular}{lllllll}
\hline & 2018 & 2017 & 2016 & 2015 & 2014 & 2013 \\
\hline P2P Consumer Lending & $\$ 195.29$ & $\$ 243.80$ & $\$ 157.60$ & $\$ 73.09$ & $\$ 21.78$ & $\$ 6.62$ \\
$\begin{array}{l}\text { P2P Business Lending } \\
\begin{array}{c}\text { Balance Sheet Business } \\
\text { Lending }\end{array}\end{array}$ & $\$ 21.08$ & $\$ 10.33 .02$ & $\$ 61.59$ & $\$ 43.70$ & $\$ 10.50$ & $\$ 2.20$ \\
$\begin{array}{c}\text { Balance Sheet Property } \\
\quad \text { Lending }\end{array}$ & $\$ 11.02$ & $\$ 1.19$ & $\$ 0.57$ & $\$ 0.00$ & $\$ 0.00$ & $\$ 0.00$ \\
$\begin{array}{l}\text { Balance Sheet } \\
\quad \text { Consumer Lending }\end{array}$ & $\$ 9.78$ & $\$ 31.17$ & $\$ 12.43$ & $\$ 3.21$ & $\$ 0.72$ & $\$ 0.09$ \\
$\begin{array}{l}\text { P2P Property Lending } \\
\text { Invoice Trading }\end{array}$ & $\$ 5.73$ & $\$ 9.14$ & $\$ 11.40$ & $\$ 7.12$ & $\$ 1.62$ & $\$ 0.26$ \\
Debt-based Securities & $\$ 0.85$ & $\$ 0.22$ & $\$ 0.47$ & $\$ 0.03$ & $\$ 0.02$ & $\$ 0.01$ \\
\hline
\end{tabular}

As mentioned earlier, despite China remaining as the global market leader in alternative lending, wide-spread closures of P2P and balance sheet lending platforms have occurred due to the implementation of increasingly strict regulations. Since July 2018, the absolute number of firms, as well as the trading volume of China's P2P lending platforms, have shown a continuing downward trend month by month. According 
Table 4.2 Global alternative lending in USD billion (exclusive of China figures)

\begin{tabular}{lllllll}
\hline & 2018 & 2017 & 2016 & 2015 & 2014 & 2013 \\
\hline $\begin{array}{l}\text { P2P Consumer Lending } \\
\text { Balance Sheet Business } \\
\text { Lending }\end{array}$ & $\$ 31.99$ & $\$ 19.30$ & $\$ 24.40$ & $\$ 27.77$ & $\$ 9.44$ & $\$ 3.49$ \\
$\begin{array}{c}\text { Balance Sheet Property } \\
\text { Lending }\end{array}$ & $\$ 11.02$ & $\$ 1.19$ & $\$ 0.57$ & $\$ 0.00$ & $\$ 0.00$ & $\$ 0.00$ \\
$\begin{array}{c}\text { Balance Sheet Consumer } \\
\text { Lending }\end{array}$ & $\$ 9.40$ & $\$ 15.34$ & $\$ 3.05$ & $\$ 3.09$ & $\$ 0.69$ & $\$ 0.09$ \\
$\begin{array}{l}\text { P2P Business Lending } \\
\text { P2P Property Lending }\end{array}$ & $\$ 7.59$ & $\$ 5.27$ & $\$ 4.93$ & $\$ 4.60$ & $\$ 2.46$ & $\$ 0.77$ \\
$\begin{array}{l}\text { Invoice Trading } \\
\text { Debt-based Securities }\end{array}$ & $\$ 3.88$ & $\$ 3.20$ & $\$ 4.36$ & $\$ 1.56$ & $\$ 0.14$ & $\$ 0.02$ \\
\hline
\end{tabular}

to the data from WDZJ (P2P online loan industry portal in China), as of November 30, 2019, the number of operating marketplace lending platforms in China was 456, a decrease of $87.24 \%$ compared to 3574 (historical peaks) in December 2015; the monthly trading volume in November 2019 dropped to 50.623 billion, having fallen by almost $80 \%$ compared to its peak in 2017.

When we remove China from the alternative finance equation (Table 4.2), we see considerable annual growth across seven of the eight applicable alternative finance models. As expected, P2P Consumer Lending is the largest model even when China's activity is removed, and we note a $66 \%$ annual growth from $\$ 19.3$ billion in 2017 to $\$ 31.99$ billion in 2018. Balance Sheet Business Lending ( $\$ 14.95$ billion) and Balance Sheet Property Lending ( $\$ 11.02$ billion) became the second and third largest models, respectively. 2018 was marked by considerable rapid growth of balance sheet models, though it is important to note that more than half of the FinTech firms operated according to the P2P lending model as well. This suggests that there is increasing emphasis on firms to take on origination risk, moving away from exclusively matching models.

\section{Regional Variances}

Regional volumes of crowdlending are summarized in Table 4.3. When we consider where crowdlending activities are geographically concentrated (while excluding China), the United States (cumulative lending 


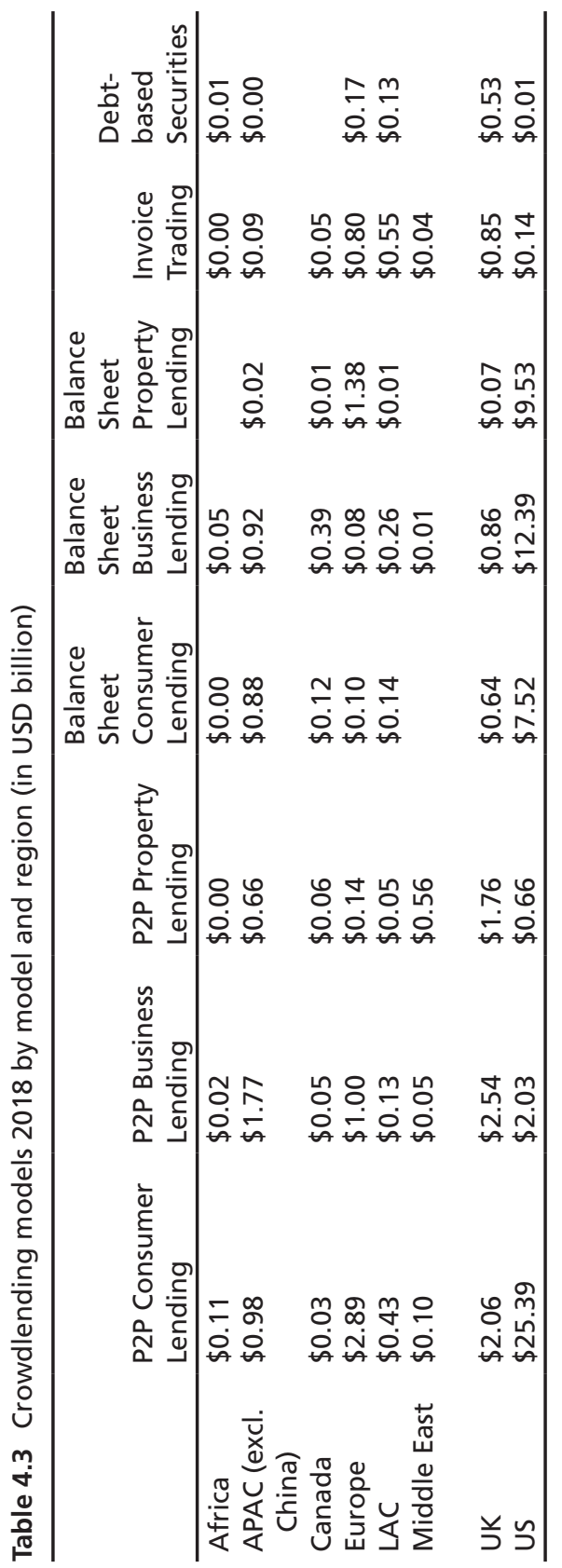


$\$ 57.7$ billion) ranks first, followed by the United Kingdom ( $\$ 9.3$ billion), the Asia-Pacific ( $\$ 5.3$ billion) and Europe ( $\$ 6.6$ billion). Moreover, if we look at the breakdown of lending activity by model type, we see that certain regions have greater emphasises on P2P lending activities versus balance-sheet lending activities. In Europe and the United Kingdom, for instance, there is a greater emphasis on P2P lending models, while in the United States and Canada, a greater emphasis is placed on balance sheet lending models.

As has been mentioned on a few occasions, the largest volume driving model is P2P Consumer Lending. However, it is worth mentioning that when we consider lending that was directed to business borrowers, nearly $\$ 28$ billion dollars went to start-ups, SMEs and business entities. Interestingly, a large proportion of business borrowers came from P2P Consumer Lending platforms, receiving a consumer loan in order to support their business funding needs.

Businesses, particularly SMEs, are using various Digital Lending products to meet their working or expansion capital needs. To illustrate the importance of these channels for SME financing, we provide insights from the United Kingdom, which earned a reputation as a leader in P2P Business Lending, as well as an environment in which SME finance is recorded systematically.

Sources of UK SME Finance are presented in Fig. 4.4. The Bank of England estimates that $£ 57.7$ billion was lent to SMEs by national banks in 2018, which represents a slight increase compared to last year's figure of $£ 57$ billion (UK Finance 2018). By comparing the UK P2P Business Lending volume against that of the UK Finance annual estimate of new loans to SMEs, it has shown that business crowdlending has increased its share of total lending steadily from just $0.3 \%$ in 2012 to $14.55 \%$ in 2018 .

Assuming that the vast majority of borrowers in peer-to-peer business lending are, in fact, small businesses with an annual turnover of less than $£ 2$ million, the chart below shows that the volume of P2P Business Lending in the United Kingdom is estimated to be equivalent to $34.8 \%$ of all bank lending to small businesses in 2018, almost $20 \%$ increase against the previous year. Therefore, P2P Business Lending is becoming an increasingly important contributor to overall SME financing in the United Kingdom in comparison to bank lending channels. 


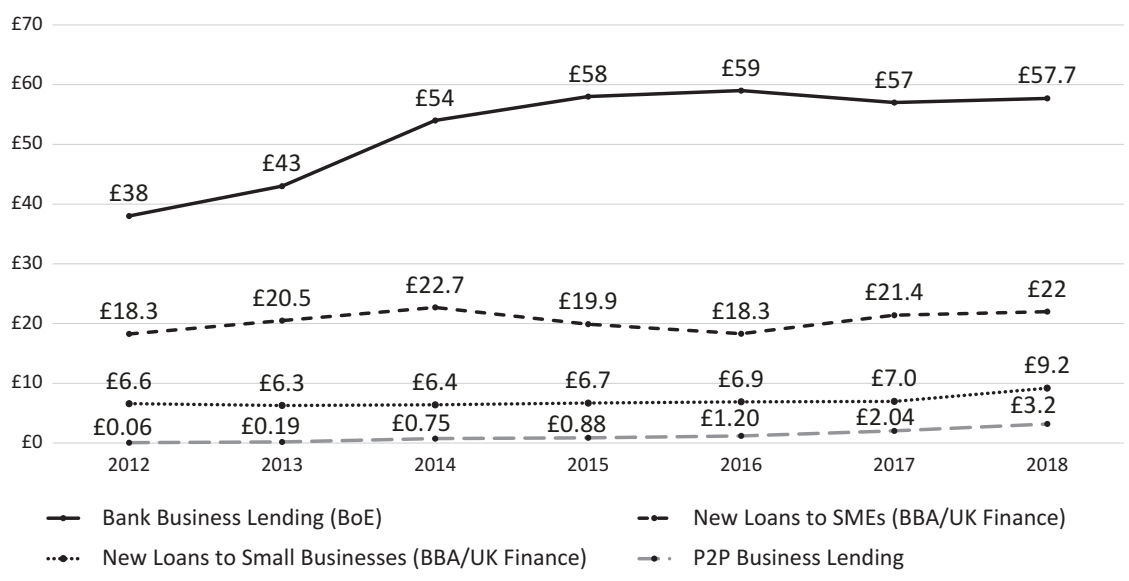

Fig. 4.4 Sources of UK SME finance 2012-2018 (in billion GBP)

\section{Risk Assessment in Crowdlending}

A fundamental problem underlying crowdlending is that of asymmetrical information (Leboeuf and Schwienbacher 2018), especially as it relates to mitigating potential risks presented when evaluating potential borrowers. Bachmann et al. (2011) refer to several key determinants that P2P Lending firms must evaluate in order to combat principal-agent problems and provide an overview of the financial characteristics of the borrower as the main indicator of creditworthiness.

Individuals seeking to lend via a P2P lending platform will not always have the requisite tools or skill set to comprehensively assess risk. Therefore, the platform often conducts an analysis of potential borrowers, assigning appropriate risk bands before offering credit. Whilst individual investors must still assess and determine the levels of risk they are willing to take, the risks associated with certain borrowers are often determined by the platform itself.

While in-house methodologies used by platforms for loan risk assessment are difficult to ascertain, as these are proprietary and disclosure is limited (Bank for International Settlements and Financial Stability Board 2017), they usually assess a borrower based on a number of set indicators. 
Such indicators include the borrower's existing credit (using traditional credit scoring), any capital or collateral that may exist, the capacity to repay the loan (debt-to-income ratio), and the conditions which the borrower is willing to adhere to. In some cases, platforms may employ an alternative underwriting process using algorithmic-based approaches to credit scoring and non-traditional data, alongside more traditional methods, to determine if the loan is of an acceptable risk level.

When underwriting an $S M E$ borrower, the credit assessment requirements are usually more robust than in the case of individual borrowing. In such cases, a platform will typically restrict lending to firms with less than three years of credit history and will require recent filed company accounts and information on company management. In some cases, the platform may also restrict lending to firms with a certain level of annual turnover (for example-requiring more than USD \$50,000 in annual turnover at minimum). Furthermore, in the case of underwriting a property loan, the platform should ideally assess the underlying asset, its location and sector, as well as procure independent valuations on the property and reassure itself that appropriate permission has been granted for any planned development. The platform should also assess the proposed exit strategy (sale, refinance etc.) for the property.

\section{Alternative Credit Analytics}

Crowdlending platforms may employ more varied and sophisticated credit assessment practices than traditional financiers. FinTech credit platforms may access a range of potential borrowers' data, which may not be typically sourced and analysed by banks. However, some 'mainstream' credit providers are also incorporating alternative credit analytics into the credit approval process. The types of data, include location-based information, social networking information, hardware data, online shopping and other online behaviour, but also more diffused data on educational attainment and performance, as well as labour market profile and performance (Hale 2019). The lender feeds available data into their algorithm to establish creditworthiness. As algorithms are generally proprietary, it is difficult to ascertain which data points are used and how they are 
weighted, when determining a credit rating. As a rule, however, there appears to be more evidence of previously excluded borrowers being accepted than of previously accepted borrowers being rejected based on alternative data (ibid.). In this context, machine learning can also be used to analyse data captured during the credit analysis phase. It can also be used to gather data on borrowers with a thin credit file.

While most platforms do not yet offer instantaneous, automated credit approval, some platforms can provide loan approval and disbursement within a few hours (for example, via mobile money). Others are working to bring approval times down to a few minutes. Alternative credit analytics reduces the need for case-by-case manual approval thus increasing the efficiency of the loan approval process.

\section{Pricing}

As crowdlending fundamentally occurs online, it reduces operating costs for credit intermediaries by removing the need for physical branches while allowing heavy (or full) automation of loan application, credit risk assessment and pricing processes (Bank for International Settlements and Financial Stability Board 2017). They are also not reliant on legacy infrastructure as banks may be and as a result, pricing will not be impacted by normal pricing considerations of traditional bank lenders. In addition, platforms may fall outside of certain licensing or other regimes, thus reducing regulatory or compliance costs. A study by Autonomous Research (2016) found that the ratio of operating expenses to total costs was less than $2 \%$ for Lending Club, a consumer and business P2P lending platform in the United States, and 6\% for the largest traditional lenders.

For these reasons FinTech lending platforms may offer lower interest rates for borrowers and/or higher returns to investors (Bank for International Settlements and Financial Stability Board 2017). Research has shown varied outcomes, however, with some studies showing little difference in borrower interest rates and investor rate of return given a similar risk profile (De Roure et al. 2016). It is sometimes difficult to compare the two rates due to a lack of equivalent loans. 


\section{Ethical Considerations in Crowdlending}

Taking into consideration recent experiences with irresponsible lending leading to high levels of personal lending via credit cards (Richards et al. 2008), which was further exacerbated by the subprime lending upheaval (Gilbert 2011), have all left their mark, and were part of the reasons for the emergence of alternative crowdlending channels. However, these problems were created by individuals who failed in their moral duties when making decisions that later led to significant harmful consequences from default and bankruptcy and all the way to suicide (Gilbert 2011; Richards et al. 2008).

Such moral pitfalls are also relevant for operators of crowdlending platforms, which must strike a delicate balance between business survival and growth and the intermediation of responsible lending. Furthermore, at a macro level, it remains to be seen to what extent does crowdlending reduces or increases long-term indebtedness of borrowers overall, as well as its relative burden on their economies. Research on these aspects of crowdlending are virtually absent and require further attention due to the importance of ethical practice for the well-being of all stakeholders involved.

\section{Loan Defaults \& Provision Funds}

Some loan defaults are inevitable. Platforms therefore recommend that investors diversify their portfolio on-platform to offset some of the negative effects of default. For example-Funding Circle, a UK-based P2P business platform, recommends a minimum investment of $£ 2000$ split across at least 200 loans (McCorquodale 2018). Platforms can sometimes offer provision funds to protect investors from default-a small proportion of monthly loan repayments are placed into a segregated fund. In the event of a default, the provision fund may be utilised on a discretionary basis to ensure that investor repayment occurs as expected. The level of protection and the breadth of coverage depends upon the policy of the platform, as well as the characteristics of different loan cohorts. 
While diversification across a large number of borrowers already provides lenders with substantial protection against default and loss (Milne and Parboteeah 2016), defaults do occur. In such cases, platforms attempt to extract as much of the value of the loans from the borrower as is possible within their responsible lending obligations. This involves a combination of soft interventions as well as legal ones carried out according to contract or to insolvency law. For example, the platform may, in acting for investors/creditors, appoint an administrator or receiver, and coordinate with other creditors. Or they might enforce against the security pledged by the borrower. In practice, recoveries are rarely a core competence of the platform operator and thus are often outsourced to debt collection agencies (Bank for International Settlements and Financial Stability Board 2017).

In this context, several academic studies have sought to identify key determinants of crowdlending defaults. Here, a study by Serrano-Cinca et al. (2015) analysing data from Lending Club, has showed that default was associated with borrowers with lower annual income, higher levels of indebtedness, shorter credit histories, and loan purpose where small business and education exhibiting highest likelihood of default. A different study by Lin et al. (2017) was conducted in the context of a Chinese crowdlending platform and showed that higher default rates were recorded among men vs. women, younger vs. older, divorced vs. married, low vs. highly educated individuals, short vs. long working experience, those working for small companies vs. those working for large companies, those who have high debt to income ration vs. those with low debt to income ratio, and those who have a delinquency history vs. those that don't have such history. Furthermore, the higher the amount of monthly repayments the higher likelihood of default. Overall, studies suggest that platforms capture many of the risks in their assessments, and the credit or risk ratings they present are good predictors of default likelihood (SerranoCinca et al. 2015; Emekter et al. 2015).

In addition, an interesting insight has been highlighted in a study by Ge et al. (2017), which tapped into the unique context of Chinese crowdlending, where social media is tightly intertwined with platform profiles. Their analysis found a significant decrease in loan default rate and increase in default repayment probability, when such information 
was shared by the platform on the borrower's social media accounts. This indicates that borrowers are deterred by potential social stigma, and that social information can be used both for credit scoring and default reduction and repayments.

\section{Lender Characteristics}

Both Individual or retail lenders/investors are non-professional individuals, that typically fall into one of three categories: (1) certified high networth or sophisticated investors; (2) ordinary investors who receive regulated advice (e.g. from a financial advisor); or (3) ordinary investors who self-certify and invest within a regulated prescribed cap (e.g. cap on the amount invested by an individual at a defined percentage of wealth or income, or a cap on the amount that can be invested in a single loan product).

Individual lenders may also be accredited or unaccredited, depending upon the jurisdiction. In many countries there are restrictions that allow only for accredited individuals to participate in digital lending. Accreditation permits individuals to purchase securities that are not registered with financial authorities or are public.

For example, the CCAF has produced an extensive investor-profiling for the UK FinTech credit market (Zhang et al. 2017). The results reveal that P2P Lending investors in the United Kingdom tend to be predominantly males aged over 55, with undergraduate degrees and earning above the average $(-£ 26,500)$ per annum. They also tend to have some experience in investment or finance. Elsewhere in Europe, Oxera (2015) showed that awareness of P2P lending was associated with higher education and higher income.

The CCAF's research into the risk perceptions of United Kingdom alternative finance investors (Zhang et al. 2017) found that investors in P2P consumer loans see the asset class as similar to managed funds in terms of risk profile and should thus expect similar returns. P2P business loans, on the other hand, are seen as riskier, and of comparable risk level to listed equities. Property P2P is ranked somewhere in between the two. 


\section{Institutionalization of Investment in Crowdlending}

Institutionalization refers to the proportion of volume which can be attributed to institutional investors, such as pension funds, mutual funds, asset management firms and banks in what is otherwise labelled as 'the crowd'. This excludes individual investors, such as accredited or unaccredited investors. However, the influx of institutional funding from traditional financial institutions, coupled with the increasing involvement of high net worth investors, is also blurring and pushing the boundaries of original conceptualization of the P2P Lending model.

To a certain degree, the involvement of institutional investors in crowd finance may be controversial. There is some evidence that they might have historically derived better returns on platforms than those platforms' individual investors (Mohammadi and Shafi 2017). Here, when institutions are able to self-select loan parts on a more granular basis than individuals, and if they get first pick of the loans on offer, then not only will they derive higher returns, but also make it very difficult for individual investors' portfolios to be optimised.

Figure 4.5 presents the share of institutional versus retail investors in crowdlending. Though retail investment remains the main driving force

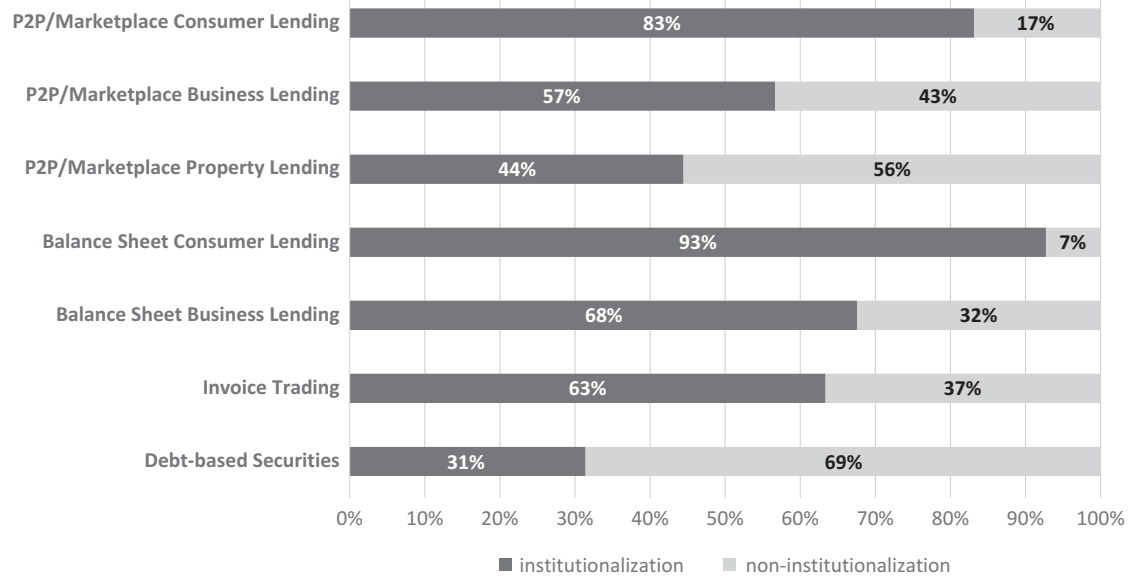

Fig. 4.5 Institutional vs. retail investors in crowdlending (globally) in 2018 
of alternative finance volumes, institutional investors also contributed significant sums. The sources of institutional funding vary significantly between models, although P2P lending models tend to attract investment from traditional banks, pension funds, hedge funds and asset management firms. Public and governmental funders, such as local authorities, also actively lend through such channels. In the United Kingdom, during 2017 (Zhang et al. 2018), 40\% ( $£ 815$ million) of the P2P Business Lending volume came from institutional investors, a sharp increase from $28 \%$ in 2016. The corresponding figure for P2P Consumer Lending was $39 \%$ ( $£ 554$ million) in 2017.

According to CCAF Global Report (2020), certain lending models lend themselves to greater institutionalization. In 2018, on a global basis, models of consumer lending are heavily influenced by institutional engagement, with balance sheet activities also having considerable influence from institutions. Regionally, the United States is heavily driven by institutional investors with $85 \%$ of funding originating from institutional investors. Africa and the Middle East, on the other hand represent regions with lowest proportion of institutional investments, with 17\% and $12 \%$ respectively. In all other regions (Asia Pacific, Canada, Europe, Latin America, and the UK), institutional investors account for close to $50 \%$ of funding.

\section{Matching}

For crowdlending models to be successful, the platform must efficiently match compatible borrowers and lenders. This may be done manually or automatically, based on investor preferences. Retail investors may prefer to manually select the loans they invest in, whilst institutional investors may establish auto-investment criteria with the platform to reduce transaction time and costs. Platforms have an incentive to automate loan selection, to simplify the loan selection process and to reduce transaction costs.

Investors have numerous ways of participating in a digital lending platform. Early P2P Lending models allowed individuals to select the specific loans they wanted to participate in, and, on some platforms, 
bidding for loan parts in an auction at a price of their choice. However, what are commonly referred to as 'self-select' and 'auction' options are becoming increasingly rare. Instead, automated loan selection has become popular practice. In such process, lenders selecting 'investment criteria', which the platform uses to 'auto-invest' the lender's money in loans meeting that criteria.

The most common practice in automation is known as 'Automated Lender Diversification'. Such approach implies that the lender is a passive investor, being matched against available loan parts/tranches that adhere to his or her predetermined preferences in terms of duration, risk appetite, amount, interest rate, etc. The platform will diversify exposure to new loans within the loan book that meet the investors pre-set selections. In this context, an approach growing in popularity, especially in the United States and the United Kingdom, is the 'Managed Portfolio Approach'. In this case, lenders may select from two or three 'managed' lending options, where they are no longer selecting their desired duration or a specific interest rate. Rather, they will be joining a portfolio that offers a range of acceptable return, and the platform diversifies lender funds by exposing them across the loan book that fits the lender's 'managed option' (e.g. Zopa Cor \& Zopa Plus). To ensure investors receive a consistent product, the platform will continuously move loans into and out of their portfolio so that the portfolio as a whole has the promised attributes.

Such automated assignment mechanisms are likely to attract increased scrutiny from regulators, as they could be construed as constituting investment advice, portfolio management, collective investment, or multilateral trading facilities. This may restrict platforms from offering the service or increase licensing requirements.

\section{Success in Crowdlending}

Success in crowdlending is associated with fulfilment of loans, indicating that target sums for a loan were successfully raised from prospective investors. A recent literature review by Shneor and Vik (2020) has identified nine persistent variables which were associated with successful 
loan fulfilment across multiple studies. First, with respect to borrowers, various signals of risk have been associated with success. Indeed, earlier studies show a positive association of credit scores and success (e.g. Kuwabara et al. 2017; Pope and Sydnor 2011), a negative association between debt to income ratio and success (e.g. Larrimore et al. 2011; Pope and Sydnor 2011), and positive association between previous successful loan raising and success in later loan raising (e.g. Barasinska and Schäfer 2014; Chen et al. 2017). In addition, studies suggest that female borrowers are more successful than men (e.g. Chen et al. 2017; Pope and Sydnor 2011), and this has sometimes been related to asking relatively smaller loans.

Second, certain loan terms were associated with greater success. Unsurprisingly, studies show that successful loans were associated with lower sums (e.g. Kuwabara et al. 2017; Yum et al. 2012), shorter timehorizons (e.g. Galak et al. 2011; Lee and Lee 2012), and higher interest rates (e.g. Feng et al. 2015; Larrimore et al. 2011). Furthermore, success was also positively associated with longer stated duration of campaigns (e.g. Larrimore et al. 2011; Lee and Lee 2012), and higher levels of onsite crowd interactions with borrowers via comments and Q\&A (e.g. Lee and Lee 2012; Yum et al. 2012).

\section{Conclusion}

Crowdlending emerged as the leading model of crowdfunding in both scope and scale in every region. It is considered as both a challenge and supplement to traditional credit service providers by opening opportunities for investment and borrowing for wider groups of people. For lenders, it offers new investment opportunities, often involving better returns than some alternative investment channels, as well as opening to incorporate new small-scale investors that have not enjoyed such opportunities before. For borrowers, it offers new channels to access credit, often either offered at better terms or by including groups that have previously been marginalized and underserved by traditional credit service providers.

In the current chapter we present the brief history of crowdlending, its diversity of models, the current state or the industry, as well as the 
underlying mechanisms and principles guiding platform operations including risk assessment and the matching of borrowers and lenders. The discussion is supported by a review of related research, while highlighting trajectories of industry development trends.

\section{Implications for Research}

While receiving some attention, opportunities for research into crowdlending realities remain abundant. First, while most research focuses on P2P consumer lending, more research is needed into the particularities of business and property lending in the P2P model, as well as research examining alternative models to P2P including Balance Sheet lending, Invoice Trading, and Debt-based Securities. Here, with respect to all models, scholars are encouraged to examine the motivations for borrowers to use such channels vs. traditional ones, as well as the motivation of lenders to invest via such channels versus alternative investment channels. Furthermore, enhancing our knowledge about drivers of success in filling loans outside of the P2P consumer lending context may be valuable for would be borrowers and platforms that use such models. Alternatively, new research into success drivers in the P2P consumer lending space may also be conducted but should cover new national and cultural contexts beyond the United States and China, which represent most studies published thus far.

Second, of special importance are studies that may examine the impact of crowdlending in broad terms examining to which extent has it delivered on its promises. Here, studies should explore whether indeed access to credit has been improved in various contexts and social groups. Moreover, studies should examine whether crowdlending is used as a supplement or as an alternative to traditional credit services, and whether the conditions offered for such loans are indeed better than those offered elsewhere. Finally, in this context, future research may also examine the impact of crowdlending on indebtedness of individuals and organizations in different socio-economic contexts, studying whether debt burdens have increased, decreased, or remained unchanged following the use of crowdlending. 


\section{Implications for Practice}

Practical implications are evident with respect to borrowers, lenders, platforms, and regulators. First, individuals and organizations interested in borrowing should examine and educate themselves about opportunities being provided by crowdlending platforms, while comparing them to other channels of credit. Once they decide to use such services, in order to improve their chances of receiving the loan, they should provide reliable information that may reduce the risk associated with their loan requests. At the same time, research suggested that they should aim for shorter term loans and be actively engaged with prospective lenders via social and platform communication tools.

Second, in terms of lenders, would be investors should educate themselves about the services offered by various crowdlending platforms, the different investment products available, and the risks associated with them. While research shows that platform risk assessments and ratings are good predictors of loan default, investors should examine a variety of risk indicators that can better inform their decision. Furthermore, in jurisdictions where automatic assignment of loans is allowed by law, investors should consider using such options for diversification and risk spreading across a portfolio of loans that match their preferences.

Third, platforms should engage in continuous learning about service developments in the industry with focus on process automation and streamlining, as well as the adoption of advanced machine learning in risk assessment and default prediction. This would enhance crowdlending FinTech platforms to fully tap into the cost efficiencies their mode of operations was set to achieve. Furthermore, despite temptation to onboard as many loans as possible, platforms should be wary of risky loans that may tarnish their reputation among prospective investors, as well as trigger regulatory crackdown that may limit industry development beyond the required risk management.

Finally, regulators should follow the industry and engage in active dialogue with its players towards developing regulatory frameworks that balance investor and borrower protection and industry growth, or support increase of access to credit while ensuring responsible use of it. Furthermore, public authorities should be concerned with informing the public about both the opportunities and risks associated with 
crowdlending engagements through encouraging and/or requiring training for individuals and organizations that use such services to a greater scale and frequency than others.

\section{References}

Armstrong, P. (2018). Here Are The U.K. Companies That Will Be Unicorns In 2019. Retrieved January 17, 2020, from https://www.forbes.com/sites/paularmstrongtech/2018/08/13/here-are-the-uk-companies-that-willbe-unicorns-in-2019/\#308da7547c81.

Autonomous Research. (2016). Digital Lending: The 100 Billion Dollar Question. Retrieved January 19, 2020, from https://next.autonomous.com/ digital-marketplace-lenders.

Bachmann, A., Becker, A., Buerckner, D., et al. (2011). Online Peer-to-Peer Lending - A Literature Review. Journal of Internet Banking and Commerce, 16(2), 1-18.

Bank for International Settlements \& Financial Stability Board. (2017). Market Structure, Business Models and Financial Stability Implications Bank for International Settlements.

Barasinska, N., \& Schäfer, D. (2014). Is Crowdfunding Different? Evidence on the Relation Between Gender and Funding Success from a German Peer-toPeer Lending Platform. German Economic Review, 15(4), 436-452.

Barry, E. (2019). The History of US Peer-to-Peer Lending. Retrieved January 17, 2020, from https://www.finder.com/p2p-lending-usa.

Bruton, G., Khavul, S., Siegel, D., et al. (2015). New Financial Alternatives in Seeding Entrepreneurship: Microfinance, Crowdfunding, and Peer-to-Peer Innovations. Entrepreneurship Theory and Practice, 39(1), 9-26.

Chen, D., Li, X., \& Lai, F. (2017). Gender Discrimination in Online Peer-toPeer Credit Lending: Evidence from a Lending Platform in China. Electronic Commerce Research, 17(4), 553-583.

Chorzempa, M. (2018). Massive P2P Failures in China: Underground Banks Going Under. China Economic Watch [Online]. Retrieved from https://www. piie.com/blogs/china-economic-watch/massive-p2p-failures-chinaunderground-banks-going-under.

De Roure, C., Pelizzon, L., \& Tasca, P. (2016). How Does P2P Lending Fit into the Consumer Credit Market? Deutsche Bundesbank Discussion Papers. Deutsche Bundesbank. 
Dorfleitner, G., Rad, J., \& Weber, M. (2017). Pricing in the Online Invoice Trading Market: First Empirical Evidence. Economics Letters, 161, 56-61.

Emekter, R., Tu, Y., Jirasakuldech, B., et al. (2015). Evaluating Credit Risk and Loan Performance in Online Peer-to-Peer (P2P) Lending. Applied Economics, 47(1), 54-70.

Feng, Y., Fan, X., \& Yoon, Y. (2015). Lenders and Borrowers' Strategies in Online Peer-to-Peer Lending Market: An Empirical Analysis of ppdai.com. Journal of Electronic Commerce Research, 16(3), 242-260.

Galak, J., Small, D., \& Stephen, A. T. (2011). Microfinance Decision Making: A Field Study of Prosocial Lending. Journal of Marketing Research, 48(SPL), S130-S137.

Ge, R., Feng, J., Gu, B., et al. (2017). Predicting and Deterring Default with

Social Media Information in Peer-to-Peer Lending. Journal of Management Information Systems, 34(2), 401-424.

Gilbert, J. (2011). Moral Duties in Business and Their Societal Impacts: The Case of the Subprime Lending Mess. Business and Society Review, 116(1), 87-107.

Haddad, C., \& Hornuf, L. (2019). The Emergence of the Global Fintech Market: Economic and Technological Determinants. Small Business Economics, 53(1), 81-105.

Hale, T. (2019). How Big Data Really Fits into Lending. Retrieved January 19, 2020, from https://ftalphaville.ft.com/2019/03/13/1552488421000/ How-big-data-really-fits-into-lending/.

Hollas, J. (2013). Is Crowdfunding Now A Threat to Traditional Finance? Corporate Finance Review, 18(1), 27-31.

Kotarba, M. (2016). New Factors Including Changes in the Retail Banking Bustomer Relationship Management (CRM) and Their Exploration by the Fintech Industry. Foundations of Management, 9, 69-78.

Kuwabara, K., Anthony, D., \& Horne, C. (2017). In the Shade of a Forest Status, Reputation, and Ambiguity in an Online Microcredit Market. Social Science Research, 64, 96-118.

Larrimore, L., Jiang, L., Larrimore, J., et al. (2011). Peer to Peer Lending: The Relationship Between Language Features, Trustworthiness, and Persuasion Success. Journal of Applied Communication Research, 39(1), 19-37.

Leboeuf, G., \& Schwienbacher, A. (2018). Crowdfunding as a New Financing Tool. In D. Cumming \& L. Hornuf (Eds.), The Economics of Crowdfunding: Startups, Portals and Investor Behavior. Cham: Springer International Publishing. 
Lee, E., \& Lee, B. (2012). Herding Behavior in Online P2P Lending: An Empirical Investigation. Electronic Commerce Research and Applications, 11(5), 495-503.

Lin, X., Li, X., \& Zheng, Z. (2017). Evaluating Borrower's Default Risk in Peerto-Peer Lending: Evidence from a Lending Platform in China. Applied Economics, 49(35), 3538-3545.

McCorquodale, R. (2018). How to Earn a More Stable Return with Diversification. Retrieved January 19, 2020, from https://www.fundingcircle.com/blog/2018/06/earn-stable-return-diversification/.

Milne, A., \& Parboteeah, P. (2016). The Business Models and Economics of Peerto-Peer Lending. Brussels: European Credit Research Institute.

Mohammadi, A., \& Shafi, K. (2017, March). How Wise Are Crowd? A Comparative Study of Crowd and Institutions in Peer-to-Business Online Lending Markets. https://static.sys.kth.se/itm/wp/cesis/cesiswp450.pdf.

Nixon, G. (2020). Peer-to-Peer Trade Body Is Axed as Lenders such as Funding Circle, RateSetter and Zopa Join a Wider Fintech Group. Retrieved January 17, 2020, from https://www.thisismoney.co.uk/money/investing/article-7881555/Peer-peer-platforms-shut-independent-trade-body.html.

Oxera. (2015). Crowdfunding from an Investor Perspective. Retrieved January 19, 2020, from https://ec.europa.eu/info/sites/info/files/file_import/160503study-crowdfunding-investor-perspective_en_0.pdf.

Pope, D. G., \& Sydnor, J. R. (2011). What's in a Picture?: Evidence of Discrimination from Prosper.com. Journal of Human Resources, 46(1), 53-92. Popescu, G. (2016). The Complete Guide to Regulation of Marketplace Lending. Retrieved January 17, 2020, from https://lending-times.com/2016/04/21/ the-complete-guide-to-regulation-of-marketplace-lending/.

Richards, M., Palmer, P., \& Bogdanova, M. (2008). Irresponsible Lending? A Case Study of a U.K. Credit Industry Reform Initiative. Journal of Business Ethics, 81(3), 499-512.

Serrano-Cinca, C., Gutiérrez-Nieto, B., \& López-Palacios, L. (2015). Determinants of Default in P2P Lending. PLOS ONE, 10(10), e0139427.

Shneor, R., \& Vik, A. A. (2020). Crowdfunding Success: A Systematic Literature Review 2010-2017. Baltic Journal of Management, 5(2), 149-182.

UK Finance. (2018). SME Finance in the UK: Past, Present and Future. Retrieved from https://www.ukfinance.org.uk/system/files/UK-FinanceSME-Finance-in-UK-AW-web.pdf. 
Yum, H., Lee, B., \& Chae, M. (2012). From the Wisdom of Crowds to My Own Judgment in Microfinance Through Online Peer-to-Peer Lending Platforms. Electronic Commerce Research and Applications, 11(5), 469-483. Zhang, S., \& Miller, M. (2017). China's New Illegal Fundraising Topped \$36 billion Last Year. Retrieved April 30, 2019, from https://www.reuters. com/article/us-china-fraud-crackdown/chinas-new-illegal-fundraisingtopped-36-billion-last-year-idUSKBN17R11X.

Zhang, B., Ziegler, T., Garvey, K., et al. (2017). Entrenching Innovation: The 4th UK Alternative Finance Industry Report. Cambridge, UK: Cambridge Centre for Alternative Finance.

Zhang, B., Ziegler, T., Mammadova, L., et al. (2018). The 5th UK Alternative Finance Industry Report. Cambridge, UK: Cambridge Centre for Alternative Finance.

Ziegler, T., Johanson, D., Zhang, B., et al. (2018). The 3rd Asia Pacific Region Alternative Finance Industry Report. Cambridge, UK: Cambridge Centre for Alternative Finance.

Ziegler, T., Shneor, R., Wenzlaff, K., et al. (2020). The Global Alternative Finance Benchmarking Report. Cambridge, UK: Cambridge Centre for Alternative Finance.

Open Access This chapter is licensed under the terms of the Creative Commons Attribution 4.0 International License (http://creativecommons.org/licenses/ by/4.0/), which permits use, sharing, adaptation, distribution and reproduction in any medium or format, as long as you give appropriate credit to the original author(s) and the source, provide a link to the Creative Commons licence and indicate if changes were made.

The images or other third party material in this chapter are included in the chapter's Creative Commons licence, unless indicated otherwise in a credit line to the material. If material is not included in the chapter's Creative Commons licence and your intended use is not permitted by statutory regulation or exceeds the permitted use, you will need to obtain permission directly from the copyright holder.

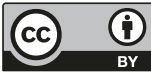

